\title{
Psychosocial and quality of life impact on patients with failed back surgery syndrome*
}

\author{
Impacto psicossocial e na qualidade de vida de pacientes com síndrome dolorosa após \\ laminectomia
}

Gabriel de Azambuja Beigin¹, Marielza Regina Ismael Martins ${ }^{1}$, Alexandre Venâncio de Souza ${ }^{2}$, José Eduardo Nogueira Forni

${ }^{*}$ Received from Pain Clinic, School of Medicine of São José do Rio Preto, São José do Rio Preto, SP, Brazil.

DOI 10.5935/1806-0013.20150007

\section{ABSTRACT}

BACKGROND AND OBJECTIVES: Triggering and chronicity of failed back surgery syndrome should consider psychosocial and emotional factors which impair quality of life. This study aimed at identifying such factors and at evaluating quality of life of failed back surgery syndrome patients.

METHODS: This is a descriptive, exploratory, comparative, cross-sectional study with quantitative approach. Sample was made up of a test group (I) diagnosed with failed back surgery syndrome $(\mathrm{n}=16)$ and a control group (II) undergoing inter-consultation in the Pain Clinic $(n=15)$. Tools were the visual analog scale and Fischer dolorimeter. WHOQOL-Bref questionnaire was used to evaluate quality of life and Beck Anxiety Inventory and Depression Inventory were used to evaluate emotional factors anxiety and depression.

RESULTS: There has been predominance of females on both groups, mean age was $42.3 \pm 5.8$ (group I), most were married and mean education was $8.4 \pm 3.0$ years. Mean pain duration was $0.7 \pm 0.3$ months after surgery in group I with lower pain threshold. Physical dimensions and social relations were the most affected on quality of life, as well as anxiety and depression levels. CONCLUSION: Our results have shown worse pain, quality of life, anxiety and depression in group I, suggesting a better knowledge of potential postoperative complications aiming at preventing the establishment of an abnormal functionality pattern.

Keywords: Chronic pain, Failed back surgery syndrome, Psycho-social impact, Quality of life.

1. School of Medicine of São José do Rio Preto, São José do Rio Preto, SP, Brazil.

2. Cancer Hospital of Barretos, Department of Psychology, Barretos, SP, Brazil.

3. School of Medicine of São José do Rio Preto, Department of Orthopedics and Traumatology, São José do Rio Preto, SP, Brazil.

Submitted in August 05, 2014.

Accepted for publication in February 20, 2015.

Conflict of interests: none - Sponsoring sources: Institutional Program of Scientific Initiation Scholarships (PIBIC)/Cnpq/FAMERP.

Correspondence to:

Gabriel de Azambuja Beigin

Avenida Brigadeiro Faria Lima 5416

Departamento de Ciências Neurológicas

15090-000 São José do Rio Preto, SP, Brasil.

E-mail: gabrielbeigin@gmail.com

(C) Sociedade Brasileira para o Estudo da Dor

\section{RESUMO}

JUSTIFICATIVA E OBJETIVOS: O desencadeamento e a cronificação da síndrome dolorosa pós-laminectomia deve considerar fatores psicossociais e emocionais, que comprometem a qualidade de vida. O objetivo deste estudo foi identificar esses fatores e avaliar a qualidade de vida de pacientes com síndrome dolorosa pós-laminectomia.

MÉTODOS: Trata-se de um estudo descritivo, exploratório, comparativo, de corte transversal e abordagem quantitativa, com amostra de um grupo teste (I), com diagnóstico de síndrome dolorosa pós-laminectomia $(\mathrm{n}=16)$ e um grupo controle (II) submetido a interconsulta na Clínica da Dor $(\mathrm{n}=15)$. Os instrumentos foram a escala analógica visual e o dolorímetro de Fischer. Para avaliar a qualidade de vida, foi utilizado questionário WHOQOL-Bref e para os fatores emocionais ansiedade e depressão, o Inventario Beck de Ansiedade e de Depressão.

RESULTADOS: Na amostra dos dois grupos houve predomínio do gênero feminino, média de idade de $42,3 \pm 5,8$ anos (grupo I), maioria casada e média de escolaridade de $8,4 \pm 3,0$ anos. $\mathrm{O}$ tempo médio de dor foi de $0,7 \pm 0,3$ meses após a cirurgia no grupo I com limiar de dor mais baixo. As dimensóes físicas e relaçóes sociais foram as mais comprometidas na qualidade de vida, assim como os níveis de ansiedade e depressão.

CONCLUSÁO: Esses resultados mostraram pior dor, qualidade de vida, ansiedade e depressão no grupo I, sugerindo maior conhecimento de possíveis complicações pós-operatórias buscando não permitir que se estabeleça um padrão anormal de funcionalidade.

Descritores: Dor crônica, Impacto psicossocial, Qualidade de vida, Síndrome pós-laminectomia.

\section{INTRODUCTION}

Failed back surgery syndrome (FBSS) is characterized by residual or persistent pain after lumbar spine surgical procedures being increasingly a common modern medicine entity $^{1}$. Although the prevalence of persistent pain secondary to the involvement of lumbosacral joints has been described in controlled studies as approximately $15 \%$ to $45 \%$, the prevalence of pain after surgical intervention has not yet been studied ${ }^{2}$. 
People with chronic pain defined as persistent (beyond the normal injury healing time and for more than three months) have further physical incapacity, make more use of analgesics, as well as look for emergency units with more frequency. This implies a higher volume of expenditures with not worked days ${ }^{3}$. It is also observed that when such people are submitted to several interventions, these may lead to unsatisfactory and inconclusive results, leading them to adopt passive, manipulating and hostile attitudes, originating inadequate results of analgesic and rehabilitating therapies ${ }^{4}$.

Some studies report that poor surgical results may come from incorrect low back pain diagnosis, such as: rheumatologic affections, primary or secondary spinal tumors, vascular affections or pelvic inflammatory disease, among others ${ }^{5,6}$. Several factors have been pointed as contributing to triggering and chronicity of lumbar painful syndromes, especially psychosocial and emotional factors, which impair quality of life $(\mathrm{QL})^{7}$.

In light of this context, this study aimed at identifying clinical and psychosocial factors and at evaluating QL of FBSS patients.

\section{METHODS}

This is a descriptive, exploratory, comparative, cross-sectional study with quantitative approach. FBSS patients were included, that is, persistent lumbar pain or early recurrence before three months after surgical herniated disc procedure (group I / $\mathrm{n}=16$ ), of both genders, without cognitive deficit, seen by the Pain Clinic, Base Hospital / FAMERP. Patients were admitted to specific postoperative low back pain ambulatory. Exclusion criteria were patients with evidences of metabolic, inflammatory or oncologic diseases, or with segmental instability evidenced by imaging exams. All patients have signed the Free and Informed Consent Term (FICT). Patients were allocated in two groups: test-group (I), with FBSS diagnosis $(n=16)$ and control group (II), submitted to interconsultation in the Pain Clinic, without diagnosis of musculoskeletal or neurological diseases, without history of previous surgery, with recommendation to perform hiking (pelvic pain, vascular, hormonal causes). Group II was made up of individuals paired for age and education with regard to group I $(n=15)$. Subjects were evaluated with a semi-structured interview to characterize socio-demographic and clinical data (age, gender, marital status, education, pain duration, social losses).

With regard to lumbar region affections, patellar and ankle reflexes were evaluated and classified as normal, increased, decreased or abolished ${ }^{8}$, and Laségue signal, when positive, indicated root involvement.

Fischer dolorimeter ${ }^{10}$ was used to evaluate pain, the procedure of which was to apply a pressure perpendicular to skin surface at a speed of $1 \mathrm{~cm} / \mathrm{s}$ on muscle motor points where nerve roots are, observing possible increases in root sensitivity, until the pressure sensation became pain, while a pressure gage would record force. Lower values indicated lower pain thresholds. Motor point was used as a reference to assure procedure reproducibility and also with the advantage of evaluating always the same site. Dolorimetry was performed on both sides for both groups. We have also applied the visual analog scale (VAS) ${ }^{11}$ which is a horizontal $10-\mathrm{cm}$ line where the left edge means no pain and the right edge the worst possible pain. Individuals were oriented to mark a point on the line, equivalent to their pain intensity. VAS is a simple and reliable tool to evaluate pain both in clinical and research situations.

Generic WHOQOL-Bref questionnaire ${ }^{12}$ was used to evaluate QL. This questionnaire is made up of 26 items evaluating 4 domains: physical, psychological, social relations and environment. Answers to all WHOQOL-Bref questions are obtained with a Likert-type scale with five points where scores may vary from 1 to 5 , in addition to two questions about general quality of life, jointly calculated to generate a single independent score, called overall or "general quality of life". To calculate domains scores, indices of component facets summarize the domains to which they belong. Both domains and general QL are measured in the positive direction, that is, higher scores mean better QL.

Emotional factors, such as anxiety and depression, were respectively evaluated by Beck Anxiety Inventory (BAI) ${ }^{13}$ made up of 21 items and people shall indicate in a fourpoint scale the severity of the symptom. Total score varies from zero to 63 and provides anxiety intensity evaluation. Anxiety level is classified as minimum (0-7), mild (8-15), moderate (16-25) or severe (26-63). Depression was evaluated with Beck Depression Inventory $(\mathrm{BDI})^{14}$, which is a self-applied scale, translated and validated for Brazil, made up of 21 items contemplating depressive symptoms and cognitive attitudes. Scores for each BDI category vary from zero to three, with zero corresponding to lack of depressive symptoms and three to presence of more severe symptoms. For total score, up to 15 points means lack or minimal presence of depressive symptoms, between 16 and 20 points there are evidences of mild or moderate depressive symptoms, above 20 points indicates moderate to severe depressive symptoms. Scores between 30 and 63 points mean very severe depressive symptoms.

According to FBSS morphology and treatment methods used, in this study patients were divided in two groups: group I ( $\mathrm{n}=16)$ suffering of this complication, and group II $(\mathrm{n}=15)$ control, but paired in age and social conditions. QLrelated social characteristics, depression and anxiety trends, in addition to interindividual variations related to physical evaluation, such as painful sensitivity, reflexes and Laségue signal were evaluated.

\section{Statistical analysis}

Whoqol Group syntax to be used in the software SPSS (Statistical Package for Social Science) was used. With it, the program was able to check, recode and establish domains and general QL scores. 
All subjects of both groups were submitted to a single evaluation and descriptive analysis was carried out with the Excel program. Qualitative dada were analyzed by odds ratio, and ordinal data by non-parametric tests. Significance level was 0.05 .

Este estudo foi aprovado pelo Comitê de Ética em Pesquisa da FAMERP (2384/2010).

\section{RESULTS}

Table 1 shows socio-demographic characteristics of groups with differences and similarities in several aspects, such as pain duration and social losses, loss of job and of ability to perform some routine tasks, impairing their daily lives.

Table 1. Socio-demographic characterization of studied groups

\begin{tabular}{lccc}
\hline Variables & Groups & $\mathrm{n}$ & $\begin{array}{c}\text { Mean, standard deviation and } \\
\text { frequency }(\%)\end{array}$ \\
\hline Age (years) & I & 16 & $42.3 \pm 5.8$ \\
Gender & II & 15 & $39.5 \pm 3.5$ \\
& I & 16 & Female $80(\mathrm{n}=12)$ \\
Marital status & II & 15 & Female $68(\mathrm{n}=10)$ \\
& & 16 & Single $18(\mathrm{n}=3)$ \\
& & & Married $56(\mathrm{n}=9)$ \\
& & & Divorced $18(\mathrm{n}=3)$ \\
& Widow(er) $8(\mathrm{n}=1)$ \\
& II & 15 & Single $20(\mathrm{n}=3)$ \\
& & & Married $42(\mathrm{n}=6)$ \\
Divorced $31(\mathrm{n}=4)$ \\
Pain duration & I & 16 & Widow $(\mathrm{er}) 7(\mathrm{n}=2)$ \\
(months) & II & 15 & $18.0 \pm 0.3$ after surgery \\
Education (ye- & I & 16 & $8.4 \pm 3.0$ \\
ars) & II & 15 & $8.0 \pm 4.6$ \\
\hline
\end{tabular}

As to pain threshold evaluated with Fischer dolorimeter on muscles of patients of both groups, there have been lower values for group I indicating lower pain thresholds, however without statistically significant difference. In both groups, dolorimetry was performed on the right and left sides (Table 2).

With regard to evaluated patellar and ankle reflexes, they were classified in normal, increased, decreased and abolished, observed in group I and presented in figure 1. It could be observed that from 16 group I patients, 10 (62.5\%) had abnormal results, confirming the involvement of this neural system.

According to Laségue signal (LS), GI had 11 (68\%) patients positive on both sides (R \& L), 4 (25\%) were positive just to the left and 1 was bilaterally negative.

With regard to pain perception, mean VAS score was higher for GI as compared to GII.

General QL-related variables mean was 50.8 for GI, with the physical domain as the most impaired, with score of 44.1 (Table 3).
Table 2. Mean, standard deviation and significance of dolorimetry on quadratus lumborum, vastus medialis, rectus femoris, vastus lateralis, gastrocnemius/gemeli, gluteus maximus, gluteus medius, pyriformis and abductor muscles, evaluated in all patients.

\begin{tabular}{|c|c|c|c|}
\hline \multirow{2}{*}{$\begin{array}{l}\text { Dolorimetry }\left(\mathrm{kg} / \mathrm{cm}^{2}\right) \\
\text { Muscles }\end{array}$} & Group I & Group II & \multirow[t]{2}{*}{$p$ value } \\
\hline & \multicolumn{2}{|c|}{ Mean \& standard deviation } & \\
\hline RQLP & $1.2 \pm 0.6$ & $2.0 \pm 0.6$ & 0.06 \\
\hline LQLP & $1.5 \pm 0.7$ & $1.9 \pm 0.6$ & 0.06 \\
\hline RQLD & $1.2 \pm 0.6$ & $1.7 \pm 0.4$ & 0.05 \\
\hline LQLD & $1.1 \pm 0.5$ & $1.6 \pm 0.7$ & 0.07 \\
\hline RVMP & $1.1 \pm 0.7$ & $1.2 \pm 0.9$ & 0.08 \\
\hline LVMP & $1.2 \pm 0.9$ & $1.9 \pm 0.6$ & 0.05 \\
\hline RVMD & $1.1 \pm 0.7$ & $1.7 \pm 0.3$ & 0.06 \\
\hline LVMD & $1.9 \pm 0.6$ & $2.5 \pm 0.8$ & 0.06 \\
\hline RRFP & $1.6 \pm 0.7$ & $2.0 \pm 0.5$ & 0.08 \\
\hline LRFP & $1.7 \pm 0.4$ & $1.8 \pm 0.4$ & 0.06 \\
\hline RRFD & $1.7 \pm 0.3$ & $1.8 \pm 0.7$ & 0.06 \\
\hline LRFD & $1.7 \pm 0.4$ & $2.8 \pm 0.4$ & 0.07 \\
\hline RVLP & $1.7 \pm 0.3$ & $1.6 \pm 0.4$ & 0.06 \\
\hline LVLP & $1.7 \pm 0.3$ & $1.4 \pm 0.4$ & 0.05 \\
\hline RVLD & $1.7 \pm 0.4$ & $2.5 \pm 0.4$ & 0.06 \\
\hline LVLD & $1.6 \pm 0.3$ & $1.8 \pm 0.3$ & 0.06 \\
\hline RGP & $1.8 \pm 0.4$ & $1.8 \pm 0.4$ & 0.06 \\
\hline LGP & $1.5 \pm 0.2$ & $2.0 \pm 0.4$ & 0.06 \\
\hline RGD & $1.6 \pm 0.4$ & $1.8 \pm 0.7$ & 0.08 \\
\hline LGD & $1.5 \pm 0.4$ & $2.0 \pm 0.4$ & 0.07 \\
\hline RGMAP & $1.7 \pm 0.4$ & $1.7 \pm 0.3$ & 0.07 \\
\hline LGMAP & $1.7 \pm 0.3$ & $1.9 \pm 0.5$ & 0.06 \\
\hline RGMAD & $1.5 \pm 0.2$ & $1.8 \pm 0.3$ & 0.07 \\
\hline LGMAD & $1.6 \pm 0.4$ & $2.5 \pm 0.4$ & 0.08 \\
\hline RGMEP & $1.3 \pm 0.6$ & $1.7 \pm 0.4$ & 0.07 \\
\hline LGMEP & $1.4 \pm 0.7$ & $2.0 \pm 0.4$ & 0.06 \\
\hline RGMED & $1.4 \pm 0.7$ & $1.8 \pm 0.4$ & 0.05 \\
\hline LGMED & $1.6 \pm 0.4$ & $1.7 \pm 0.4$ & 0.06 \\
\hline RPP & $1.6 \pm 0.4$ & $1.6 \pm 0.4$ & 0.06 \\
\hline LPP & $1.2 \pm 0.6$ & $1.8 \pm 0.7$ & 0.07 \\
\hline RPD & $1.2 \pm 0.6$ & $2.8 \pm 0.4$ & 0.06 \\
\hline LPD & $1.2 \pm 0.4$ & $1.8 \pm 0.4$ & 0.06 \\
\hline RAP & $1.3 \pm 0.3$ & $2.0 \pm 0.4$ & 0.08 \\
\hline LAP & $1.1 \pm 0.2$ & $1.5 \pm 0.5$ & 0.05 \\
\hline RAD & $1.4 \pm 0.2$ & $1.6 \pm 0.4$ & 0.06 \\
\hline LAD & $1.4 \pm 0.2$ & $1.8 \pm 0.4$ & 0.07 \\
\hline
\end{tabular}

$R \& L Q L P=$ right and left quadratus lomborum proximalis; $R$ \& $L Q L D=$ right and left quadratus lumborum distalis; R \& LVMP = right and left vastus medialis proximalis; $R$ \& LVMD = right and left vastus medialis distalis; $R$ \& LRFP = right and left rectum femoris proximalis; $R \& E R F D=$ right and left rectum femoris distalis; R \& LVLP = right and left vastus lateralis proximalis; $R$ \& LVLD $=$ right and left vastus lateralis distalis; $\mathrm{R} \& \mathrm{LGP}=$ right and left gastrocnemius proximalis; $R$ \& $L G D=$ right and left gastrocnemius distalis; $R$ \& $L G M P=$ right and left gluteus maximus proximalis; $R \& L G M D=$ right and left gluteus medius distalis; $R$ \& LPP = right and left pyriformis proximalis; $R$ \& LPD = right and left pyriformis distalis; $R$ \& LAP = right and left aductor proximalis; $R$ \& $L A D=$ right and left aductor distalis.

${ }^{*} p<0.05$ - statistical non-parametric Mann-Whitney test. 


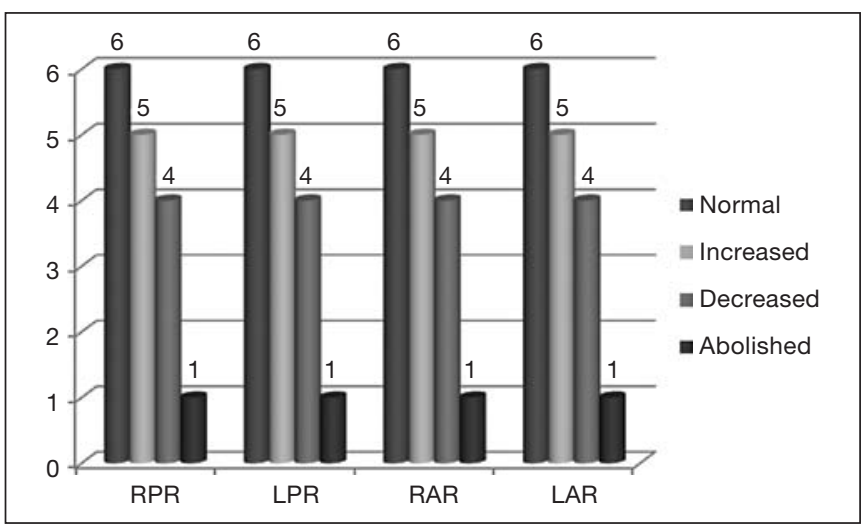

Figure 1. Presence of patellar and ankle reflexes referred by group I patients $(n=16)$

$\mathrm{RPR}=$ right patellar reflex; $\mathrm{LPR}=$ left patellar reflex; $R A R=$ right ankle reflex; LAR $=$ left ankle reflex

Table 3. Scores of pain evaluation and quality of life domains, according to generic WHOQOL-Bref questionnaire, for both groups

\begin{tabular}{lccc}
\hline Quality of life domains & $\begin{array}{c}\text { Group I } \\
\text { Mean \& stan- } \\
\text { dard deviation }\end{array}$ & $\begin{array}{c}\text { Group II } \\
\text { Mean \& stan- } \\
\text { dard deviation }\end{array}$ & $\begin{array}{c}\mathrm{p} \\
\text { value }\end{array}$ \\
\hline Physical & $44.1 \pm 13.9$ & $56.4 \pm 3.0$ & $0.04^{*}$ \\
Psychological & $50.0 \pm 24.0$ & $51.4 \pm 16.7$ & 0.08 \\
Social relations & $47.3 \pm 21.3$ & $62.0 \pm 15.0$ & $0.03^{*}$ \\
Environment & $62.0 \pm 15.5$ & $62.5 \pm 16.7$ & 0.08 \\
General quality of life & $50.8 \pm 18.5$ & $58.0 \pm 12.8$ & $0.04^{*}$ \\
Visual analog scale & $7.0 \pm 0.27$ & $5.1 \pm 0.26$ & $0.048^{*}$ \\
\hline
\end{tabular}

${ }^{*}$ Statistically significant $-p<0.05$. Mann-Whitney test.

Beck Anxiety Inventory (BAI) data analysis has shown mean of 14.5 , considered mild and without significant difference $(\mathrm{p}>0.05)$ between groups. Mean depression (BDI) was 17.75 , indicating that above 16 there are already signs of possible depression. In this statistical correlation, there has been difference between groups $(\mathrm{p}<0.05)$, which affects quality of life of FBSS patients (Figure 2).

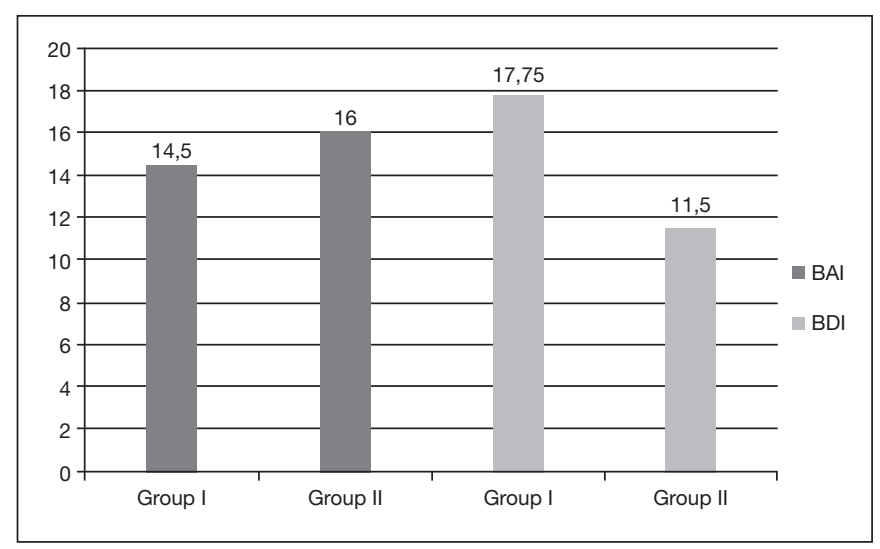

Figure 2. Numerical characteristics (mean) of anxiety and depression evaluation scores, according to Beck Inventory for group I $(n=16)$ and group II $(n=15)$

$\mathrm{BAI}=$ Beck Anxiety Inventory; BDI = Beck Depression Inventory.

\section{DISCUSSION}

The incidence of back surgery failure resulting in return of pain has been scarcely studied, however its chronicity has been reported by some authors as affecting $15 \%$ to $20 \%$ of individuals ${ }^{15}$.

Age of BSFS patients included in this study has varied from 25 to 79 years (mean of $42.3 \pm 5.8$ years), with pain duration of 13 months and moderate intensity (7.0). In a study by Teixeira et al. ${ }^{4}$ indices were similar, being different only with regard to gender, which in our study was predominantly female. With regard to pain threshold there has been no significant difference between groups.

Some authors refer a variety of factors which may induce BSFS, such as possible spinal nerve root injury, which has been surgically decompressed, non-recovery of previous trauma being a constant source of nerve or sciatic pain. In other cases, scars which may involve nervous roots and induce chronic pain, the presence of spinal structural changes which are developed above or below a spinal fusion site, recurrent herniated disc, spinal or pelvic ligament instability, among others; however, to develop an effective treatment plan, it is necessary to identify individual variations and the impact on their $\mathrm{QL}^{18}$.

So, due to the understanding of possible postoperative complications, there is the need to measure QL, social losses and emotional factors to understand the dynamics of the therapeutic process and to intervene when necessary, preventing the establishment of an abnormal functionality pattern ${ }^{19}$.

$\mathrm{QL}$ is directly related to postoperative recovery of FBSS patients, especially the physical dimension, according to a study of Meneffe et al. ${ }^{20}$ which reports that the influence of personal, cultural and affective factors is critical for satisfactory recovery and maintenance of adequate QL. The influence of those factors on patients with surgical indication may be predictor of the occurrence and expression of pain ${ }^{21}$.

North et al. ${ }^{22}$ have evaluated 102 patients with persistent or recurrent pain after back surgery (mean of 2.4 previous surgeries) and after a 5-year follow-up they have reported relief in 34\%; 15\% were retired and most have decreased or eliminated analgesics consumption. They have also recorded better prognosis for young and female patients. These results suggest that selection criteria for repeated back surgeries require further evaluations, together with a review of treatment results, and that alternative approaches should always be considered.

Individuals with pain after surgical failure (GI), in our study, had significantly higher pain scores $(\mathrm{p}<0.05)$ as compared to GII. There are few studies investigating emotional factors in this population but according to some studies, psychosocial factors have significant impact on pain, being often responsible for the chronic use of opioids $s^{1,19}$.

The social profile of this sample was also observed and referred several social losses for GI (17\% unemployment, 18\% retirement and $65 \%$ social security), for which no comparative data were found in other studies. 
Our results suggest that pain complaint in FBSS patients negatively interferes with QL and the study of pain should be encouraged and prioritized, due to the complexity, subjectivity and individuality of this subject.

\section{CONCLUSION}

Our study has observed moderate and lasting pain in FBSS patients. Physical dimension was the most impacted dimension when QL was evaluated and labor activity was affected. There has been high prevalence of depression.

Considering that there are few scientific evidences in global evaluation of such patients, knowing involved factors through tools and evaluations allows the testing of interventions aiming at improving chronic pain.

\section{REFERENCES}

1. Long DM. Failed back surgery syndrome. Neurosurg Clin N Am. 1991;2(4):899919.

2. Follett, KA, Dirks BA. Etiology and evaluation of the failed back surgery outcome. Neurosurg Q. 1993;3(1):40-59

3. Shipton EA. Low back pain and the post-laminectomy pain syndrome. S Afr Med J. 1989;76(1):20-3

4. Teixeira MJ, Yeng LT, Garcia OG, Fonoff ET, Paiva WS, Araujo JO. [Failed back surgery pain syndrome: therapeutic approach descriptive study in 56 patients]. Rev Assoc Med Bras. 2011;57(3):282-7. English, Portuguese.

5. Almeida DB, Teixeira MJ, Kaziyama HH, Yeng LT. Síndrome dolorosa pós-laminectomia lombar: avaliaçáo de 29 pacientes. Rev Dor. 2007;8(3):1067-71.

6. Kulkarni KR, Talakanti SK. Management of failed back surgery syndrome with transforaminal epidural steroid and epidural saline adhesiolysis. Indian J Pain. 2014;28(2):117-20
7. HelfensteIn Junior M, Goldenfum MA, Siena C. [Occupational low back pain]. Rev Assoc Med Bras. 2010;56(5):583-9. English, Portuguese.

8. Hoppenfeld S. Propedêutica ortopédica: coluna e extremidades. Sấo Paulo: Atheneu; 1998 .

9. Borges CA, Ximenes AC. Coluna vertebral. In: Porto CC. Semiologia médica. $3^{a}$ ed. Rio de Janeiro: Guanabara Koogan; 1997. 894-905p.

10. Fischer AA. Muscle pain syndromes and fibromyalgia. Musculoesk J Pain 1998;6(1):107-15.

11. Pimenta CAM. Escalas de avaliação de dor. In: Teixeira MD, (editor). Dor conceitos gerais. São Paulo: Limay; 1994. 46-56p.

12. Fleck MP, Louzada S, Xavier M, Chachamovich E, Vieira G, Santos L, et al. [Aplication of the Portuguese version of the abbreviated instrument of quality life WHOQOL-brev]. Rev Saude Publica. 2000;34(2):178-83. Portuguese.

13. Leyfer OT, Ruberg JL, Woodruff-Borden J. Examination of the utility of the Beck Anxiety Inventory and its factors as a screener for anxiety disorders. J Anxiety Disord. 2006;20(4):444-58.

14. Gorenstein C, Andrade L. Validation of a Portuguese version of the Beck Depression Inventory and the State-Trait Anxiety Inventory in Brazilian subjects. Braz J Med Biol Res. 1996;29(4):453-7.

15. Deyo RA, Tsiu-Wu YJ. Descriptive epidemiology of low-back pain and its related medical care in the United States.Spine. 1987;12(3):264-8.

16. Manchikanti L, Pampati V, Baha AG, Fellows B, Damron KS, Barnhill RC. Contribution of facet joints to chronic low back pain in postlumbar laminectomy syndrome: a controlled comparative prevalence evaluation. Pain Physician. 2001;4(2):175-80.

17. Ostelo RW, Costa LO, Maher CG, de Vet HC, van Tulder MW. Rehabilitation after lumbar disc surgery: an update Cochrane review. Spine. 2009;34(17):1839-48.

18. Shapiro CM. The failed back surgery syndrome: pitfalls surrounding evaluation and treatment. Phys Med Rehabil Clin N Am.2014;25(2):319-40.

19. Manca A, Eldabe S, Buchser E, Kumar K, Taylor RS. Relationship between health related quality of life, pain, and functional disability in neuropathic pain patients with failed back surgery syndrome. Value Health. 2010;13(1):95-102.

20. Menefee LA, Frank ED, Doghramji K, Picarello K, Park JJ, Jalali S, et al. Self-reported sleep quality and quality of life for individuals with chronic pain conditions. Clin J Pain. 2000;16(4):290-7.

21. Häkkinen A, Kautiainen H, Sintonen H, Ylinen J. Health related quality of life after lumbar disc surgery: a prospective study of 145 patients. Disabil Rehabil. 2005;27(3):94-100.

22. North RB, Campbell JN, James CS, Conover-Walker MK, Wang H, Piantadosi S, et al. Failed back surgery syndrome: 5-year follow-up in 102 patients undergoing repeated operation. Neurosurgery. 1991;28(5):685-91. 